\title{
Corporal and Discourse Fuzzy Boundaries. The Partaking of Experience in Simone de Beauvoir's Monologue
}

\author{
Alexandra Roxana Marginean, (lecturer PhD)
}

Romanian-American University, Romania

Doi:10.19044/esj.2018.v14n20p1 ～URL:http://dx.doi.org/10.19044/esj.2018.v14n20p1

\begin{abstract}
The paper sets out to analyze the multiple mirroring taking place between various aspects of the narrative reality in Simone de Beauvoir's Monologue and suggested in terms of broken imagery. We seek to prove the unity and harmony existing in this disheveled text, which one may find difficult to make sense of upon a first reading. The aim is to reveal the way in which, in fact, the smallest details symphonically converge towards the main idea(s), in a finely-tuned and thought-over masterwork that the short story at hand obscures itself from being upon a superficial glance. Starting from corporal references, which abound in the text, we analyze the way in which these intertwine with and reflect the main themes - femininity and feminism, aggression and trauma, sexuality, motherhood, the obsession of contrasts, material and metaphorical obstructions and flows, patriarchy and truthfulness - and are reunited towards a bitter (and, as the protagonist claims, a more honest) interpretation of reality. The approach also proposes the acceptance of paradox, present in the notion of unity in difference, of fuzzy concepts, pointing to deconstructive construction and to the creation of broken identity. The demonstration ultimately resorts, for explanatory reasons, to the image of the partaking, as a metaphor for the process of using bits and pieces to the purpose of attaining communion, pieces which both aren't and at the same time are the Whole.
\end{abstract}

Keywords: Identity, fragmentariness, oxymoron, feminism, truthfulness

\section{Introduction:}

This analysis intends to start from discursive elements and pair them with the interpretative contents which they are meant to render or send to, showing to what complex extent this mirroring is accomplished through a type of syncopated narrative. Moreover, we will try to answer the question if there is any intention to hide, rather than reveal things from the protagonist's part, 
and if she is merely a symbolically short-sighted, erratic, hateful, mentally broken woman, or there is something superior or enlightening to her vision. Finally, the metaphor of partaking comes to the fore for the process unfolding under the implied reader's eyes, and we will explain why we consider it so suitable for the intentions of the text at hand.

In connection with seeing the protagonist's narrative-confession as a Eucharistic experience, we have also intentionally chosen the word "corporal" rather than "corporeal" in the title, as, unlike the latter term, which refers to something "of or for the body as opposed to the spirit" (Longman Dictionary of English Language and Culture, 2003: 289), the former has spiritual overtones, meaning, besides something connected to the body, "a linen cloth on which the eucharistic elements are placed" and being also used in the phrase "corporal works of mercy" in the traditional believers' language, and referring to the "seven helpful acts such as sheltering the homeless and burying the dead" (Merriam-Webster Dictionary since 1828). Hence, the latter combines the physical and the spiritual aspects in one, illustrating the interpretations provided by the text as, firstly, an experience of sharing-partaking, as well as, secondly, the necessity of unity of and in difference, in its various realizations in de Beauvoir's work, which we will be exploring in what follows.

\section{Five-sense, corporal references}

The whole story is built around the states that a woman, Murielle, experiences while locking herself away from the world in her apartment, and the tormenting thoughts that come to her mind in the midst of her distress. The first thing we notice at the level of the text is the bodily references. These are not only multiple, but also unusual, in more than one sense. For one, they are rendered with almost violent intensity, sometimes vulgarity. Then, they are touching on all the five senses. What is more, the observations are filled with contradiction and oxymoron. The woman-narrator's introduction of and reference to notions reminds one of fuzzy concepts. She seems to enjoy putting together opposites because the newly created unit is more impactful, but not only for that. Before we attempt to see the rationale behind this style, let us introduce textual illustrations for the aspects we have just mentioned.

The corporal references involve primarily the senses of sight and hearing. The visual is based on a contrast between white and black, light and darkness. Color is removed from the scene wherever it may introduce itself unawares: the female protagonist is drawing the curtains on the "stupid colored lanterns and the fairy lights on the Christmas trees" aligned outside the house, in the street (de Beauvoir, 1969). The character sits in her room, distraught, bothered to the extreme by the young, good-for-nothing gadabouts passing in their fancy cars, trying to impress. They usually ride a "white convertible with black seats" (Ibidem) (emphases mine). Whenever she walks in the street in their 
proximity, she wears "slanting sunglasses" (Ibidem), primarily to shun eye contact as much as possible, but also in order to block vivid colors - sunglasses also being a means to make tints fade out and to darken images, filtering and reflecting light.

Noises are brought into her comments obsessively: "Engines revving brakes" and "horns", the above-mentioned fellows "whistled" and hit their "bawling klaxons" (Ibidem). She wishes they "smashed into one another" under her window (Ibidem). All their racket strains her nerves: "they are shattering my eardrums I've no more plugs", "They thump thump thump in my head I can see them I can hear them" (Ibidem). The quotes above highlight words describing loud noises made by machines or things - with the exception of the whistle. This dehumanization of the sounds contributes to their violence and stressful nature. Moreover, a lot of terms refer to noises that are repetitive or prolonged, which also adds to the stress that they produce - "revving", "horns", "bawling", "shattering", and the "thump" that gets repeated, appearing three times consecutively. Pressure is achieved through the diversity of the sounds she hears as well. Last but not least, their violence is suggested by the fact that some refer to a clash between objects or to objects being destroyed - much like the person's soul and psyche: "smashed", "shattering", "thump". Also, more evoke sounds that are powerful and of low vibration, rather than soft and of a high vibration, which sends to aggressiveness.

The contrastive aspect of the narrative bits appears while the character describes sounds as well. At some point, she remarks: "I'd rather have my ears shattered than hear the telephone not ringing. Stop the uproar the silence: sleep." (Ibidem) We are faced with the paradoxical idea that silence can be loud, deafening even - in the same way in which an earsplitting sound can be too loud - a contention that may seem nonsensical at a first glance. However, what the character refers to here is the pain that she is experiencing for the tension she is going through while waiting for the phone to ring, for both fearing and wishing for it at the same time. The absence of noise, then, can be even more annoying and violent. As we realize this, the opposition used is no longer a logical transgression, but turns into an image of a richer, more powerful and complex logic.

\section{Reasons for the use of contrast}

We shall try at this point to extract some reasons for the use of contrast and of the descriptions above, trying to infer the messages that they convey. We realize, as we read and integrate the images the protagonist throws at us, that the rendered realities that initially seem incomprehensible are actually filled with meaning, and create some sort of synergies inside which meaning acquires new potency. In order to make sense of these, one needs to filter the images through the sieve of psychology and the mechanisms of the psyche, as 
in this light they become comprehensible. Enhanced empathy is required to decode them, but once the hermeneutics occurs, we realize that the new image is more complex and detailed, so the understanding of meaning is, so to say, upgraded.

The use of oxymoron points to an incapacity to name and label experience, i.e. to integrate it - in other words, it is evidence of trauma. Trauma is the reason why colors are barred because they seem too merry and incongruous with one's state of mind, while only black and white are acceptable. Dismissal of colors is a rejection of joy in one's life, on the one hand, whereas, on the other, it may symbolically hint at a desire for clear contexts, at the craving which could emerge against the background of too much uncertainty and anxiety which the psyche attempts to evade. Avoidance of joyous colors and oversensitivity to loud noises indicate depression, as well a precarious psychological state in which the person imminently risks losing her mental health and balance in a more permanent sense.

Putting together opposite realities, along with an exaggerated sensitivity to noises point to the person experiencing aggression, the obsessive clashes suggesting a victim of violence. It is not clear at the beginning whether this violence is just psychological, or it has manifested in physical abuse as well.

Oxymoron suggests, as well, a more open-minded approach to reality. Alongside fuzzy logic and fuzzy concepts, it may reveal a search for a new vision, a desire to refute givens and escape prosaic outlooks, while looking for one's own truth. The protagonist suffers as a result of the others' lies, because of patriarchy, of convention and of social pretense, which she perceives as dissociations from the truth, leading to fragmentariness in both perception and between human beings. So, putting together notions that find themselves at the opposite poles of reason resembles an attempt to recompose the initial unity of things, when all was one, and out of which to start carving meaning anew. It seems an effort to go back to chaos or nothingness as a primordial matter or raw material, out of which creation can start and fresh perspectives can emerge. Destruction and Genesis are intertwined, and the former is necessary in order to obtain the premise for a Big Bang of meaning. Deconstructive endeavors are based on this type of logic and permeate modern thinking.

Reunion of contrary realities happens, as we have seen so far, at the level of the visual, auditory and wording in the story. It also occurs as far as states are concerned, as the protagonist vacillates between hyper excitability and numbness. Agitation helps her stay active and vigilant, with her mind functioning within superior parameters and processing at high speed, but it also exhausts her and, consequently, she finds herself in dire need of rest and sleep. Staying awake and anxious favors the flow of the storytelling and the revelation of truth, which she obviously wants since she has embarked upon 
the task of self-expression, but, paradoxically, all she is trying to do ever since the story begins is go to sleep and bar every visual and auditory stimulus coming from the outside: "And I shan't get a wink yesterday I couldn't either", "I'm going to have another sleepless night my nerves are going to be frazzled" (Ibidem). These divergent tendencies - towards both recounting and ceasing the narrative - coexist.

Blocking the flow of story-telling is paralleled by blockages at the level of the body. She stuffs herself with sleeping pills into unconsciousness. What is more, the blocking drugs come in the form of suppositories as well, as if in order to emphasize the idea of stuffing and obstructing: "I've taken so many sleeping pills they don't work anymore and that doctor is a sadist he gives them to me in the form of suppositories and I can't stuff myself like a gun." (Ibidem) Also, another obstruction of orifices is that of the ear canals with ear plugs, which she intends to use (although she considers them "utterly repulsive") (Ibidem).

The metaphor of orifice obstruction, i.e. that of an attempt to block flows, may be interpreted as a fear of finally making sense of chaos and of finding in the end a horrific explanation or key for what one has lived. The oscillation between the desire to block and to allow flow can be associated with a compulsion in psychology, or a moth-to-the-flame type of behavior. The protagonist is drawn between two tendencies which are equally powerful searching, and abandoning the search. Fear of the prospective horror of either an unpleasant truth or nothingness is what determines her to choose at some point the blockage of thoughts, experience, understanding, story-telling, out of the dread of what she could find out if she pursues her endeavor further. It is a desire to (forever?) postpone revelation when/since revelation could bring terror and confirm one's worst fears. It is a defense mechanism of putting off facing the un-recountable or unbearable, a form of self-imposed censorship while, at the same time, one is fighting the compulsion to tell, to let the pieces reconnect and solve the puzzle for both herself and the receiver of information.

The basic mechanism of survival for any living organism is its exchanges with the environment - of matter, energy and information. Without these natural flows, inadaptability and death would consequently occur. The character's refusal to comply with this law shows suicidal tendencies, which are, however, backgrounded and merely hinted at, since the main mode remains the fragmented telling or flow allowance.

The character manifests an abhorrence of the physical in general, another kind of blockage, both of the body and in the mind. Refusal to eat can be assigned to the same inclination to stop flows and the natural cycle of life and living itself. Eating is, also, yet another bodily reference. The others' "stuffing" or gluttony comes in contrast with her frugality or even nausea with respect to food ingestion: "They are stuffing themselves with cheap foie gras 
and burned turkey they drool over it" (Ibidem). Also, while in the funfair as a child, she even refuses the ice-cream handed to her by her mother: "they stuffed an ice into my hand there was nothing I wanted to do with it I threw it away" (Ibidem).

Sexuality can be seen in the same manner as eating, from the point of view of the protagonist's problem with it. There is a moment in the story when food and sexual consumption are clearly associated, one with the other and both with uncleanliness and nausea: "This is the moment they make love on beds on sofas on the ground in cars the time for being sick sick sick when they bring up the turkey and the caviar it's filthy" (Ibidem). Also, "stuffing" is a word used to designate both eating and sexual intercourse metaphorically. She refuses sexuality in the same way in which she refuses eating, as if trying to avoid flow, fluidity, joy and (pro)creation. The inability to let oneself go with the flows of life means fear of relinquishing control and an obsessive need to cling to it, seize it and hold on to it, in a desire to avoid surprises and pain. Such a fear characterizes traumatized individuals, the protagonist included. We shall see if this is the sole explanation for her attitude - and why she would need to resort to this kind of behavior - or if the textual references reveal others.

\section{The problem of sexuality}

The character's awareness of the sexual appears at a very early age, when she loathed being squeezed between her mother and father while watching the fireworks in a park, intuiting and sensing the sexual energy between them: "Papa lifted Nanard onto his shoulders so that he could see the fireworks and I stayed there on the ground squashed between them just at prick level and that randy crowd's smell of sex" (Ibidem). While her mother plays with the protagonist's brother Nanard in her bed, the girl feels not only excluded, but seems to infer something else with respect to this game, deemed inappropriate and dirty: "I heard them tickling one another he says it's untrue I'm disgusting of course he's not going to confess they never do confess indeed maybe he's forgotten", "She used to wander about her brothel of a room half naked in her white silk dressing gown with its stains and cigarette holes and he clung around her legs it makes you really sick mothers with their little male jobs" (Ibidem). In her description of the situation, there is a hint to a little too much sensuousness involved in the play, mixed with a feeling that there is something wrong going on. The suggestion, we realize, is that her brother Nanard might have been abused by their mother, and does not remember it. Another hint at her mother's preference for boys or younger men is made when she is presented as a predator having lured and sexually abused Albert, her presumably significantly younger son-in-law, then making him marry her daughter (Ibidem) perhaps just to have him nearby in case she wanted to abuse 
him again. These harsh comments and inferences are made by the protagonist, who is her daughter.

Reproduction and birth are seen not as natural and positive, but as lewd and licentious, acquiring hyperbolized dimensions. Nanard has five children, naturally as a result of physical acts. The obsession that these become for the protagonist is illustrated by her nightmare-like image of overpopulation, in which people walking in the streets resemble an ant farm, for the destruction of whom famines are "not nearly enough" (Ibidem). The earth is "infested" with people - not populated, the choice of verb being indicative of a vision of human race as a parasitic one. The apocalyptical image above is strengthened by another horror-film-like one that she imagines while looking at the moon, of sexual genitalia spouting offspring incessantly (Ibidem). These images of humankind as alienated and horrific are a theme in de Beauvoir's writings: the body is a "site of struggle" for "control and loss of control, boundary and boundaries breached", there is "a war between the individual and the species" - the species is an "invader" appropriating the woman's body, reducing it to the "reproductive apparatus" consumed by a "monstrous ovulation", the woman herself becoming a monster (Scarth, 2004: 140). The male seed invading the female body resembles an infection with a virus, a possession (Ibidem), just like in an alien horror film.

Merely living in the world can make one ill, as the world and people are unclean, the concrete filth making allusion to a moral one: "They're making me ill there's a foul taste in my mouth and these two little pimples on my thigh they horrify me. I take care I only eat healthy foods but even so there are people who muck about with them hands more or less clean there's no hygiene anywhere in the world the air is polluted not only because of the cars and the factories but also these millions of filthy mouths swallowing it and belching it out from morning till night: when I think I'm swimming in their breath I feel like rushing off into the very middle of the desert: how can you keep your body clean in such a lousy disgusting world you're contaminated through all the pores of your skin" (de Beauvoir, 1969). The images of decay culminate with imagining her own rotten body after death: "They'll find a rotting corpse behind the door I'll stink I'll have shat the rats will have eaten my nose" (Ibidem). She goes as far as having fantasies of an apocalypse, as the wiping of the human race off the face of the earth would equate a welcome cleaningup: "Wind! It's suddenly started to blow like fury how I should like an enormous disaster that would sweep everything away" (Ibidem).

When she reaches this point, when she seems not only unmoved by Armageddon, but quite eager to see it happening, we realize that her misanthropist attitude mirrors a phobia determined by what she has suffered at the hand of man and people because of people's stupidity, hypocrisy and meanness, and for the trauma of her daughter's death: "I don't give a fuck for 
humanity what has it ever done for me I ask you. If they are such bleeding fools as to murder one another bomb one another plaster one another with napalm wipe one another out I'm not going to weep my eyes out, a million children have been massacred so what? Children are never anything but the seed of bastards it unclutters the planet a little they all admit it's overpopulated don't they? If I were the earth it would disgust me, all this vermin on my back, I'd shake it off. I'm quite willing to die if they all die too. I'm not going to go all soft-centered about kids that mean nothing to me. My own daughter's dead and they've stolen my son from me." (Ibidem) The last sentences help us realize that she is not a heartless monster but merely a heart-broken, grieving mother, suffering bitterly from the death of her daughter, which she feels she cannot bear, yearning to reach out while all the people she knows turn their backs on her, needing her own mother's forgiveness and to retract the curse and blame she has put on her daughter, wanting reconciliation.

For the same reasons, that people have the common features of being dirty and gluttonous everywhere, tourism is just hysteria, like the Christmas and Easter celebrations: "Stinking filth dirty washing cabbage stalks what a pretentious fool you have to be to go into ecstasies over that! And it's the same thing everywhere all the time whether they're stuffing themselves with chips paella or pizza it's the same crew a filthy crew" (Ibidem).

There is a strong desire from the narrator's part to clearly delimit herself from people who engage in sexual or physical acts. By doing so, she fanatically claims, on a number of occasions, that she is "clean" (Ibidem), a "proper little woman" - a phrase that gets repeated into a leitmotif for four times (Ibidem), which points again to her obsession to stay clear of sexual encounters and of any kind of physical contact: "I'm clean I'm straight I don't join in any act" (Ibidem). Because sexuality is an obsession, she comes to equate any touch or form of physicality with sexuality and with something vulgar, unclean and immoral.

Another reason why she might have a problem with sexuality besides potential childhood or adolescence abuse (perhaps her own along with Nanard's) is having witnessed her father's indiscretions in the area: "He was dancing with Nina belly to belly she was sticking out her big tits she stank of scent but underneath it you got a whiff of bidet and he was jigging about with a prick on him like a bull" (Ibidem). She draws a parallel between this image of her father and what she imagines is going on upstairs in the present, and so the bawdy images of erections, bodily specific fluids and the sort keep coming: "they're rubbing together sex to sex [...]" etc. (Ibidem).

Both sexuality and eating presuppose taking in something coming from the outside. Since she has a problem with accepting givens, this is illustrated in her attitude towards these processes. Still, she obsesses over the two activities. Sexuality has pregnancy as a potential outcome, and both can mean 
accepting man and, symbolically, patriarchal order and ideology: "a mother is engaged in a struggle for her subjectivity. The physiological event of pregnancy blurs with the social imposition of femininity; the fetus merges with the patriarchy" (Scarth, 2004: 143). Within patriarchal ideology, women's sexual objectification and maternity are seen as "destiny" (Ibidem: 138), as natural functions, and, in this respect, having a child is "enforced maternity" (Ibidem). This explains the tense relationship Murielle has with her daughter, Sylvie, as Sylvie is a reminder of oppression in a double sense: Murielle's own and her daughter's future, potential one. Sylvie is a double mirror for her own suffering.

Sexuality is also rejected as a form of objectification. As Scarth puts it, woman sees herself reduced to flesh by the male actual and symbolical gaze, and since being flesh is disparaged, she experiences horror of her own body and condition: "What I do want to make clear, however, is Beauvoir's insistence on the extent to which patriarchal mythology shapes and constrains women's lived experience of their bodies. And I want to take seriously her claim that to know oneself to be a free being, yet experience oneself as flesh, in a culture that denigrates and devalues the flesh, could be an experience of horror" (my emphasis) (Ibidem: 118). Male gaze appears as disturbing and offensive as early as the first pages of Monologue, along with the heroine's attempt to cover herself - her body and face behind sunglasses - and hide from it.

In the sexual act, both participants are reduced to flesh, so at risk of being a mere object, there is an ambiguity whether they are empowered or vulnerable, a freedom in their abandonment to each other, a partnership made between equals, and also a sort of protest against the universe for fleetingness; thus, a form of superior, deep communication is established between the ones involved (Ibidem: 125-6). This outlook is presented by Simone de Beauvoir in The Ethics of Ambiguity, whereas the one of the oppressed, objectified woman is predominant in The Second Sex (Ibidem: 126). Scarth detects the evolution of vision taking place in the passage from one work to the other (Ibidem: 127). Conversely, incapacitation when it comes to sexuality is interpretable in this light as an impossibility to communicate the traumatic and unspeakable, which is why the full drama of what has happened and of her grief is rendered through the type of interrupted language flow present in Monologue, and also why it is only revealed with tremendous difficulty towards the end of the story.

\section{The question of truth(fulness)}

Murielle admits to needing food and central heating - so, to having bodily needs - only barely and fleetingly: 'I'm dying of thirst I'm hungry but it would slay me to get up out of my armchair and go to the kitchen. You freeze to death in this hole only if I turn up the central heating the air will dry out completely 
there's no spit left in my mouth my nose is burning." (de Beauvoir, 1969) Although she acknowledges having these bare necessities, just as the need for a family - more precisely a husband, she deems them only a buffer between herself and people's meanness and a means towards getting their respect: "Bloody hell, I want to be treated with respect I want my husband my son my home like everybody else." (Ibidem)

The point made above is a core one in understanding her mindset. A significant part of her lamentation and trauma come from what she considers the main injustice of patriarchal mentality: that the presence of a man in a woman's life earns her respect from the others, automatically legitimating a woman's existence as valuable, making her thoughts and attitudes worthy of attention (even when they are worthless in essence) because they transmit the underlying assumption of acceptance of man (her having accepted man and man having accepted her). One of Murielle's bitter realizations is that any lie wrapped up in this type of reality can pass as the truth or is turned a blind eye on, whereas the real truth, that women suffer injustice if they refuse to comply to this social norm, that they have valuable opinions of their own, that they prove stronger, more intelligent and more commonsensical than men but indulge in a lie because "men hold together so the law is so unfair" (Ibidem), is obscured. In her life she feels she has been tricked by men and people in general and their pretense, so she has ended up fighting for the custody of her son Francis and for holding on to her home while struggling to make ends meet, and all these because she has refused to play by their rules and be a trickster of men, i.e. a hypocritical, indulgent liar, like other women whom she disconsiders, calling them "fat cows" (Ibidem) and unlike whom she has refused to "swoon go down on my knees in admiration before him" (Ibidem) when this "him" is nothing but a "puffed-up little pseudo-Napoleon" (Ibidem). She sees men as having an unjustifiably positive image of self, and also as suffering from insensitivity and a God complex, starting from the presupposition that women need protection because incapable of self-care or vulnerable, as children, at best. Her perspective has been voiced in feminist criticism: "if it is true that it is as the eternal child that women are exploited, it is also true that it is as the (impossible) absolute subject that men are barred from crucial dimensions of their humanity" (Bergoffen, 2000: 105). The protagonist's outlook is that men indeed miss out on humanity, on essential features for their evolution as human beings - such as empathy, sensitivity, reasonableness, superior insight, generosity - on account of being granted the power role automatically by society and, the implication goes, unjustifiably, as it is this very default assignation that maims them in the accomplishment of their potentialities and in their evolution.

From this refusal of hypocrisy comes the opposition she creates between ordinary women and people who are insincere, and herself, whom she 
positions at the other pole, of sincerity and truthfulness. The word "clear" is used countless times to refer to herself, in conjunction with "clean", "pure", "frank" and "straight"; these appear either alone or in compounds: "clearsighted", "clean-minded" (de Beauvoir, 1969). Also, she describes herself as one who tears people's masks off, exposing their lies: "I tear masks off", pulling their "mental earplugs": "I force them to the truth" (Ibidem). Truth is essential to her because people's avoidance or doctoring of it is what she feels has engendered a dramatic, false chain of events and interpretations in her life: they blamed her for not attending to her daughter Sylvie properly on account of no longer having a stable relationship with a man, which made her seem incapable of both wifehood and motherhood, and a grumpy, unmethodical, unpleasant, even impossible person, which ultimately naturally drove her daughter away making her keep to herself, which caused Sylvie a nervous breakdown and finally determined her to commit suicide; her mother's carelessness and overall disinterest and irresponsibility were also the reasons why Sylvie was not saved at the last moment, which her mother could have done if she had opened the door to the girl's room that appalling morning. Murielle, on the other hand, has a different explanation. She claims that it was due to people's narrow-mindedness and hypocrisy, of judging a single woman and mother as always being at fault for breaking up with a man (whereas in reality she was more honest because not complacent with lie), instead of supporting her, that they poisoned Sylvie against her mother, causing the girl to become estranged: "They are the ones who killed her [...] treated her as a martyr [...] she took her part seriously she distrusted me she told me nothing [...]. She needed my support my advice they deprived her of them they condemned her to silence", so they are "murderers" (Ibidem). Truth is paramount for the protagonist in clearing her name, getting the burden of guilt off her shoulders, and in order to be able to keep on living.

The character suffers because of the others' lack of truthfulness and from being bullied around by people's misinterpretations, not to mention as a result of the version of facts that the ones holding power in society present of her. This is illustrative of the author's ideas on the qualities she associates with women in general. In an interview, Simone de Beauvoir explained that, for men, the one thing that has primordial importance is the domination of the world, the practical side of life, knowing how things work and making them work; power and mastery are overriding (Brison 2003: 190-1). Being deprived of power, women do not have the flaws that come with it, e.g. "selfimportance, the fatuousness, the complacency, the spirit of emulation", but have "devotion" and "more irony, more detachment, more simplicity [...] play fewer roles, wear fewer masks", and, most importantly, they are possessors of "truthfulness" - "and that's a quality they should keep and should also transmit 
to men" (Ibidem: 191). De Beauvoir's heroine voices this outlook on and idea of femininity.

We should not overlook or conceal one aspect that appears in criticism regarding de Beauvoir's heroines. These are accused of "bad faith" (O'Flynn, 2009: 75; Holland, 2003: 11). De Beauvoir herself complained that readers do not pick up the hints she throws about the characters in The Woman Destroyed, otherwise they would see them as guilty - "coupable" (de Beauvoir qtd, in Holland, 2003: 19). Holland explains that this view starts from the premise that there is a unique truth to begin with, and this may not be the case (Holland, 2003: 11). O'Flynn points out that having bad faith is "self-deception" (O'Flynn, 2009: 75). I think that Holland indeed makes a point with her statement, but it is not necessarily a relevant one here, since it would mean that we could not characterize anyone as truthful or lying, and this is, in my opinion, too radical of a stretch, whereas with O'Flynn one may feel the need to be more exact in defining concepts. What I mean is that there is a distinction between "bad faith", on the one hand, which involves intentionally and knowingly deceiving others, and which usually sends one to the idea of coldbloodedness in so doing, and self-deception, on the other, which is a more complex process that can be associated with more aspects. When one deludes oneself along with the others, the implications are that one is too weak - in some sense - to accept the truth. It is more on the side of being incapable or traumatized, rather than on the side of being bad or derogatory. This is an important distinction that needs to be made, and the context of the protagonist should weigh a lot in establishing her guilt or absence thereof. In Murielle's mind, if she admits to being careless in relation with her daughter - i.e. the others" "truth" - she needs to also accept that she is in part to blame for her daughter's death, which she already fears, or she would not have suffered a breakdown and been tormented (which she clearly appears to be from her discourse) and obsessed with going through the events over and over again in her mind. Her manifestations exclude the possibility of her being cold, insensitive and careless, as people perceive her to be. Besides, her discourse ramblings do not look like an attempt to cover reality, but resemble more a desire to find out the truth for herself, to understand and internalize facts and to cope with trauma. There is a significant difference between this process and what she is accused of by critics. The process we are talking about is genuine and involves truthfulness, as opposed to the other interpretation which inclines more on the side of dishonesty, trickery and hard-hearted sham. Simone de Beauvoir admits, at some point, in a preface written to another writer's book, that "although she set out to reveal the mauvaise foi of her heroines in $L a$ Femme Rompue, she had been shown how her texts ('récits') 'pouvaient être envisagés sous de tout autres aspects" (Holland, 2003: 17) and "une étude critique apporte à son écrivain des lumières inattendues sur son travail" 
(Ibidem), which means that she implicitly admits readers could not perceive in her heroines the mauvaise foi that she perhaps attributes to them.

In one of her essays, drawing on Cavell, Toril Moi constructs a parallel between looking at experience and looking at a literary piece, saying that these are acts of philosophy, because "the question of expression and experience lie at the very heart of philosophy" (Moi, 2011: 129). Also, in aesthetic judgment (passed on a work of art), or in the judgment or evaluation of one's own experience alike, "there is self-exposure" (Ibidem: 137), "It makes us vulnerable" (Ibidem), because "What I say or write will reveal my blindness and my callousness, my insights and my generosity, my failures and my achievements" (Ibidem: 129). Moi refers to de Beauvoir's writing as a kind that means to perform such exposure of ideas, approaches of the world etc. In this light, the protagonist in Monologue too, is not trying to hide or obscure her actions, but performs the courageous deed of bringing them forth for analysis, of turning upon them in order to make sense of them better. In this respect, it is an act of truthfulness just as it is one of bravery.

\section{The why of the disheveled text}

The sometimes paradoxical contrasts never cease in the narrator's commentaries, accompanying her explanations irrespective of their nature. For instance, when she describes her state of anxiety, she experiences a mixture of cold and heat. She is freezing, yet at the same time burning up, her nervous membranes dry and hot (see above) - and there is no evidence of illness, which would explain the presence of these opposite symptoms. Also, she confesses to feeling both full of life, capable of new, grand things - "a burning flame" (de Beauvoir, 1969), and tired of living, awaiting a cataclysm that would finally allow her to get some rest - "I'm tired of fighting them [...] it's exhausting I wish it would all come to an end" (Ibidem). The coming and going of experience is visible in its incoherent rendering in the narrative, in the way it occurs with brakes, turns, and periods of momentum immediately followed or interrupted by lows and silence. Through her style, the protagonist defies the logic of interaction in this type of story-telling, which is a mirror for the corporal flow-blockage inconsistencies and for the forced combination of opposite concepts (i.e oxymoron). Her narrative is filled with seizures, in a hyphenated continuum of consciousness. She breaks all the rules of classical discourse, by employing broken sentences, sentences that are elliptical of the verb, and by refusing to use punctuation marks (especially commas) even where their existence is crucial for the understanding of the text.

One other reason for resorting to this stream of consciousness, besides it being, potentially, the involuntary outcome of incapacitating mental breakdown, could also be her intention to render, by means of emotional 
effusion, the impression of truthfulness. Disorderly, unplanned and therefore unpremeditated form can function as proof of sincerity.

A third perspective is a likely run-away from pre-set forms of discourse as from an oppressive patriarchal tool meant for the taming of reality into neatness. Writing has been associated throughout history with man and Reason, mainly because initially only men had access to education. In an interview Simone de Beauvoir gave Susan Brison, upon being asked whether women should accept the use of domains such as the arts, science, literature etc. the way they were developed by men, or try to change them, de Beauvoir answered, referring to language, that "of course we must seize upon language, but in doing so we must remain aware that language bears the mark of men. It's universal but also singular" (de Beauvoir qtd. in Brison, 2003: 190). This type of thinking explains her derailment from typical narration and its rules. Her intention to nevertheless avoid deconstructing language too much is explained by the fact that a style that is too different or unusual could bar communication altogether: "I don't approve of [...] a language that is completely different from common language because I think it cuts off communication" (Ibidem: 193). This could be the answer to other critics' rebukes directed at her - feminists and not only - that her writing actually fails to strike by either novelty or originality because of a lack of imaginativeness in language and ideas. However, regrettably, the case may be, as Alison Holland noticed while synthesizing the state of criticism studies on de Beauvoir, that in reality some or most of these critics "have barely engaged with the text" (Holland, 1997: 3).

Moreover, written text opposes fact or reality in the sense signaled by a number of theorists on text and narrative. The Russian formalists distinguished between "fabula and sjuzhet: the story as a series of events and the story as reported in the narrative" (Culler, 2005: 189). The existence of this distinction was signaled by de Beauvoir (in another context), when she said that "Facts do not determine their own expression; they dictate nothing. The person who recounts them finds out what he has to say about them through the act of saying it.", sharing Sartre's perspective on the power of words to change reality (de Beauvoir qtd. in Brison, 2003: 203). Nature/reality can be seen as the truth, what is, and associated with the feminine and the uncontainable, while discourse is reality put into a shape - ordered, made sense of, but also an interpretation of reality, manipulative, restrictive, containing/limiting, partial and selective, or nuanced in a certain way that serves a certain interest. The character Murielle boasts, on a number of occasions, about her being "pure" and telling the truth, in opposition with the others' hypocrisy. Disorder in her discourse points to avoidance of thought-of and thought-through "construction" (i.e. interpretative transformation of reality), and, thus, to more honesty. 


\section{Conclusion:}

When the last scene of the short story unfolds, it also adds the final - and most revealing - touches to meaning. The protagonist has a probably imagined conversation with Tristan, Sylvie's father, over the phone, in which she proposes living together for the sake of their other child, Francis, but what starts as a truce offering ends up in venomous accusations. She feels on the edge, unable to calm down, and thinks of committing a bloody suicide by slitting her veins. The very last image is a hopeful one, of her and her two children strolling in Paradise, followed by the envious eyes of all those who had thought she was a failure as a mother - what she thinks would be the perfect revenge in the face of all those who have misjudged and wronged her. All the so-far missing bits of information come together and make sense in this ultimate interpretation, offered as she completes the last pieces of the puzzle: her utter despair and love as a mother explain the bitterness and venom she has spewed; the contrasts have derived mostly from the irreconcilable realities of her being alive whereas her daughter is dead; the rejection of food, sexuality is a rejection of life on account of her grief and absurdity of still being alive after she has buried Sylvie; the obsession with procreation and offspring comes from the painful absence and departure of her own as well, and perhaps from envy with the women who still share this condition and status; the vacillation between flows and blockages is a desire to escape reality while at the same time being faced with the necessity to go on living. The lost integrity of the body, which we initially think is the protagonist's, is actually her daughter's, who has killed herself. It parallels the strange, interrupted text (which is sometimes abrupt and other times too flowy to mind punctuation), as well as the indecisiveness of depiction which passes from one pole to another, with the use of contrastive language for the same reality. Thus, the mirroring we were bringing into discussion is achieved, the pieces come together to make sense of the initial chaos. Food and sexual consumption are subtly matched by the consumption of experience - both by Murielle and by us, the readers, of her narrative, of the understanding on which her absolution depends. The metaphor of partaking of experience makes even more sense in this way, as it means symbolically eating the bits we are fed in order to get to the re-composition of the whole and save her soul. It refers to the act of sharing - from her part and ours - and, by the reception and acceptance of her truth, to helping her acquire peace of mind, establish a communion and thus also avoid being alone by becoming reconciled with society.

The protagonist's aim is to share her experience even though and when her attitude seems to be one of hate and withdrawal from the world - at some point she confesses she would like someone to call her and be there for her, or to make up with her own mother and obtain her forgiveness despite apparently hating her. In relation to motherhood, she rejects it as a destiny, a natural 
outcome of womanhood, but is aware of it and has embraced it (or wants to) in a correct, ethical way, as de Beauvoir's "maternité libre" (Scarth, 2004: 138) - an "engagement" (Ibidem: 146), a "complex undertaking", in which the responsible mother is preoccupied with getting involved with the right ideologies of the world that her child is going to live in (Ibidem: 147), much like being a good citizen. The fact that Murielle tends towards this type of motherhood, and not the one by default on account of being a woman, is visible in the constant preoccupation in her thoughts with the education of Sylvie and Francis. This would also showcase her as a good mother despite the others' opinions, and even as one with superior understanding of what motherhood is supposed to be. In the end, it is all about sharing love and truth with the others, in all aspects of one's life.

\section{References:}

1. Bergoffen, D. B. (2000). Simone de Beauvoir: Disrupting the Metonymy of Gender. In D. Olkowski (Ed.), Resistance, Flight, Creation. Feminist Enactments of French Philosophy (pp. 97-110). Ithaca, New York: Cornell University Press.

2. Brison, S. J. (2003). Beauvoir and Feminism. Interview and Reflections. In C. Card (Ed.), The Cambridge Companion to Simone de Beauvoir (pp. 189-207). Cambridge: Cambridge University Press.

3. Culler, J. (2005). The Pursuit of Signs. Semiotics, Literature, Deconstruction. Routledge: Taylor \& Francis e-Library. Web.

4. De Beauvoir, S. (1969). Monologue. In The Woman Destroyed. Translated from French by Patrick O’Brian. New York: Pantheon Books. Kindle edition.

5. Holland, A. T. (1997). Madness in the Text: A Study of Simone de Beauvoir's Writing Practice. Thesis submitted for the Degree of Doctor of Philosophy. Newcastle University Library, 09752113 3, Thesis L6075. University Of Newcastle, Department of French Studies. Web.

6. Longman Dictionary of English Language and Culture (2003). Harlow: Pearson Longman.

7. Merriam-Webster Dictionary since 1828. https://www.merriamwebster.com. Consulted on May 26, 2018, 6:40 p.m.

8. Moi, T. (2011). The Adventure of Reading: Literature and Philosophy, Cavell and Beauvoir. In Literature \& Theology (pp. 125-140), Vol. 25, No. 2, June 2011. doi:10.1093/litthe/frr014. Advance Access publication 10 April 2011. Web.

9. O' Flynn, P. (2009). The Creation of Meaning: Simone de Beauvoir's Existentialist Ethics. In Minerva - An Internet Journal of Philosophy (pp. 67-84). ISSN 1393-614X. Web. 
10. Scarth, F. (2004). The Other Within. Ethics, Politics, and the Body in Simone de Beauvoir. Oxford: Rowman \& Littlefield Publishers, Inc. 